\title{
Ar-Ar dating of K-feldspar in low grade metamorphic rocks: Example of an exhumed Mesozoic accretionary wedge and forearc, South Island, New Zealand
}

\author{
N. Mortimer, ${ }^{1}$ S. McLaren, ${ }^{2}$ and W. J. Dunlap ${ }^{3}$ \\ Received 27 October 2011; revised 14 April 2012; accepted 22 May 2012; published 30 June 2012.
}

[1] New ${ }^{40} \mathrm{Ar} /{ }^{39} \mathrm{Ar}$ ages from detrital K-feldspars and metamorphic white micas

from the Eastern Province terranes of New Zealand have been used to investigate the thermo-tectonic history of different parts of an exhumed Mesozoic forearc basin and accretionary wedge. K-feldspars from barely metamorphosed sedimentary host rocks mainly record detrital source area ages whereas those from zeolite and prehnite-pumpellyite facies host rocks have textures and argon age spectra that indicate recrystallization during regional low-temperature metamorphism. The results contribute to a model that genetically links thermo-tectonic events across the accretionary wedge and forearc basin elements of the convergent margin, and into the Median Batholith arc probably by the Early Cretaceous and possibly by the Middle Jurassic. Thus, even though multidiffusion domain (MDD) models cannot be used to make inference on cooling histories in such situations, the K-feldspar argon thermochronometer can provide useful information on the timing of geological events in sub-greenschist facies rocks.

Citation: Mortimer, N., S. McLaren, and W. J. Dunlap (2012), Ar-Ar dating of K-feldspar in low grade metamorphic rocks: Example of an exhumed Mesozoic accretionary wedge and forearc, South Island, New Zealand, Tectonics, 31, TC3020, doi:10.1029/2011TC003057.

\section{Introduction}

[2] Potassium feldspar argon thermochronology is commonly used to help establish the cooling and exhumation history of plutonic rocks, and of amphibolite and granulite facies metamorphic rocks. Provided certain criteria are met, diffusion modeling of step-heating argon release spectra provides useful age information of rocks when they were in the temperature range $175-350^{\circ} \mathrm{C}$. K-feldspar is a moderately common detrital mineral in sandstones that have a continental provenance. However, prograde metamorphic reactions usually eliminate detrital K-feldspar in sub-greenschist facies, and K-feldspar does not grow in its own right as a metamorphic mineral in the greenschist facies. To date there are very few studies of K-feldspar being used as a geochronometer in sub-greenschist facies rocks [e.g., McLaren and Dunlap, 2006]. The purpose of this paper is twofold (1) as a case study in the use of K-feldspar Ar-Ar step-heating and laser techniques as a dating tool in zeolite and prehnitepumpellyite facies regional metamorphic rocks; (2) as a test for the thermotectonic continuity of the exhumed

\footnotetext{
${ }^{1}$ GNS Science, Dunedin, New Zealand.

${ }^{2}$ School of Earth Sciences, University of Melbourne, Melbourne, Victoria, Australia.

${ }^{3}$ Department of Geology and Geophysics, University of Minnesota, Twin Cities, Minneapolis, Minnesota, USA.

Corresponding author: N. Mortimer, GNS Science, Private Bag 1930, Dunedin 9054, New Zealand. (n.mortimer@gns.cri.nz)

(C)2012. American Geophysical Union. All Rights Reserved. 0278-7407/12/2011TC003057
}

accretionary wedge and forearc basin of New Zealand's Otago Schist and flanking terranes (Figure 1).

[3] Apatite fission track ages from the mountains of southern New Zealand largely record Neogene landscape development [e.g., Tippett and Kamp, 1993; Herman et al., 2007]. The amount of Cenozoic exhumation of basement rocks is particularly large in the western South Island (e.g., Fiordland and the Southern Alps) where it has also disturbed some Mesozoic argon thermochronological systems. For this study, whose focus is medium temperature argon thermochronometers in K-feldspar and white mica, all of our sampling was done east of the Moonlight Fault (Figure 1) in order to avoid Neogene overprints. The basement rocks that were used for this study comprise four metasedimentary tectonostratigraphic terranes. There is good control on stratigraphic age, depositional environment, provenance, detrital zircon ages, metamorphic grade, and general field relations. This makes it a good place to examine the behavior of argon in K-feldspars in different levels of exhumed Mesozoic crust.

\section{Geology and Sampling}

\subsection{Background}

[4] The New Zealand basement consists of a collage of nine major Cambrian-Cretaceous volcano-sedimentary terranes, some of which have been intruded by composite regional batholiths and variably affected by tectonometamorphic processes that produced gneisses, schists and melanges [Coombs et al., 1976; Bradshaw, 1989; Mortimer, 2004]. The diverse geology is the product of long-lived 

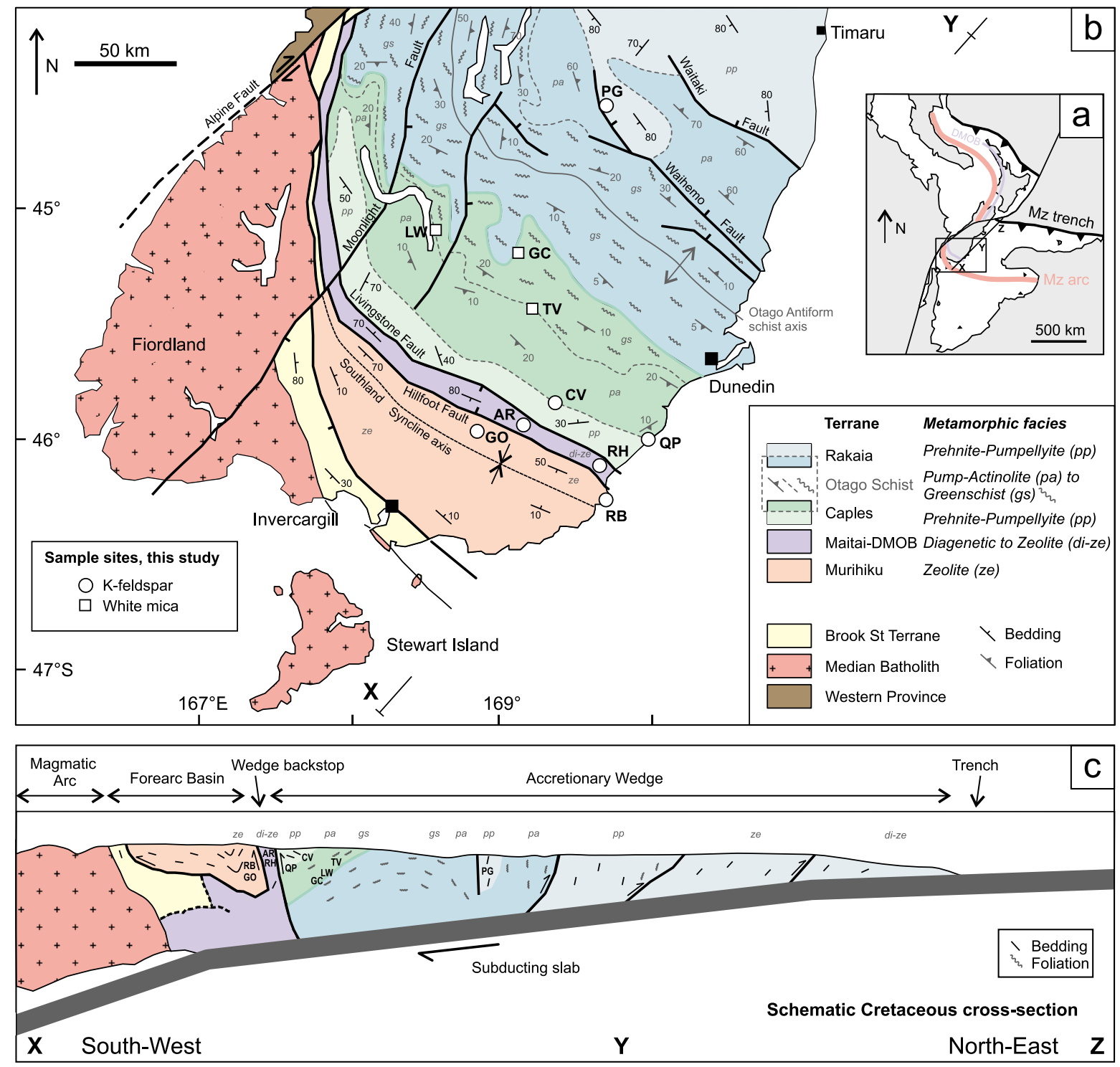

Figure 1. (a) The continent of Zealandia (white), location of main figure (box) and extent of the Dun Mountain Ophiolite Belt (DMOB), Median Batholith arc and inferred Mesozoic trench. (b) Simplified map of the basement geology of part of New Zealand's southern South Island. Geology mainly from Bishop and Turnbull [1996], Turnbull [2000], Forsyth [2001], and Turnbull and Allibone [2003]. New geochronology sample sites: PG, Pierces Gorge; GC, Gorge Creek; TV, Teviot; LW, Lake Wakatipu; GO, Gore; AR, Arthurton; RH, Romahapa; RB, Roaring Bay; CV, Clydevale; QP, Quoin Point. (c) Schematic composite Cretaceous cross section (not to scale) based on seismic line of Mortimer et al. [2002] showing the terranes, schist and batholith interpreted as components of a Mesozoic convergent margin above a subducting slab. Approximate position of samples within the Cretaceous wedge is shown, along with the metamorphic grade exposed at the present-day surface.

episodic subduction at the southern oceanic margin of Gondwana that started in the Cambrian and persisted into the Early Cretaceous.

\subsection{Rakaia Terrane}

[5] New Zealand's largest onland terrane by area, the Torlesse Composite Terrane (TCT) consists mainly of monotonous steeply dipping, tectonically imbricated feldsarenitic sandstone and mudstone [MacKinnon, 1983]. Limestone, basalt and chert and polymict conglomerate are minor lithologies. The TCT is subdivided according to age, composition and geography. The part of the TCT shown in the area of Figure 1 is the Rakaia Terrane whose clastic rocks are of Permian and Triassic stratigraphic age and were deformed in a Jurassic-Cretaceous accretionary wedge. Our three samples of Rakaia Terrane were obtained from a conglomerate band in Pierces Gorge on the north side of the Otago Schist (Figure 1 and Table 1). A detrital zircon $\mathrm{U}-\mathrm{Pb}$ age spectrum of 50 zircons from this same site has major peaks at 245 and $261 \mathrm{Ma}$, c. $30 \%$ of grains have ages 
Table 1. Sample Data ${ }^{\mathrm{a}}$

\begin{tabular}{|c|c|c|c|c|c|c|c|c|c|c|}
\hline Location & Field & P\# & NZMG & Strat. Age (Ma) & Rock Type & Facies & Min & Sieve $(\mu \mathrm{m})$ & Method & Ar Age (Ma) \\
\hline \multicolumn{11}{|l|}{ Rakaia Terrane } \\
\hline Pierces Gorge & PG1 & 75207 & H41/71608990 & $<245$ & sandstone bed & pr-pu & Ksp & $250-500$ & laser & $152 \pm 7$ \\
\hline Pierces Gorge & PG5 & 75211 & H41/71508980 & $>245$ & biotite granite clast & pr-pu & Ksp & $250-500$ & laser & $154 \pm 2$ \\
\hline Pierces Gorge & PG6 & 75212 & $\mathrm{H} 41 / 71608990$ & $>245$ & fg granite clast & pr-pu & Ksp & $250-500$ & laser & $160 \pm 4$ \\
\hline \multicolumn{11}{|l|}{ Caples Terrane } \\
\hline Quoin Point & QP1 & 64145 & I45/91134655 & Norian, $<221$ & schistose granite clast & pr-pu & Ksp & $250-500$ & furnace & $159 \pm 3$ \\
\hline Clydevale & $\mathrm{CV}$ & 64169 & G45/39795473 & ?Norian, 200-250 & pebbly sandstone bed & pr-pu & Ksp & $150-250$ & furnace & $168 \pm 3$ \\
\hline Lake Wakatipu & LW3 & 64177 & F42/76104257 & " & psammitic schist & gs-chl & mica & $125-180$ & furnace & $135 \pm 1$ \\
\hline Teviot & TV & 64248 & G43/27300374 & $"$ & psammitic schist & gs-chl & mica & $40-90$ & furnace & $147 \pm 1$ \\
\hline Gorge Creek & $\mathrm{GC}$ & 64250 & G42/18923016 & " & psammitic schist & gs-chl & mica & $75-125$ & furnace & $136 \pm 1$ \\
\hline \multicolumn{11}{|l|}{ Maitai Terrane } \\
\hline Romahapa & RH3 & 64243 & $\mathrm{H} 46 / 58832448$ & E-M Trias, 227-251 & $\mathrm{hb}$ leucodiorite clast & di-ze & Ksp & $125-250$ & furnace & $230 \pm 2$ \\
\hline Arthurton & AR1 & 64235 & $\mathrm{G} 45 / 13505020$ & E Trias, 245-251 & epid granodiorite clast & di-ze & Ksp & $125-250$ & furnace & $336 \pm 7$ \\
\hline " & AR3 & 64237 & " & " & pink granite clast & di-ze & Ksp & $250-500$ & furnace & $247 \pm 3$ \\
\hline \multicolumn{11}{|l|}{ Murihiku Terrane } \\
\hline Roaring Bay & RB6 & 64164 & $\mathrm{H} 46 / 63971320$ & $>$ Oretian, $215-222$ & biotite granite clast & ze & Ksp & $250-500$ & furnace & $183 \pm 4$ \\
\hline$"$ & RB7 & 64165 & " & Oretian, 215-222 & sandstone bed & ze & Ksp & $250-500$ & furnace & $202 \pm 3$ \\
\hline Gore & GO1 & 64212 & F45/96604670 & $>$ Otapirian, 200-206 & red granite clast & ze & Ksp & $250-500$ & furnace & $188 \pm 3$ \\
\hline " & GO7 & 64218 & " & $"$ & biotite granite clast & ze & Ksp & $250-500$ & furnace & $189 \pm 3$ \\
\hline$"$ & GO13 & 64224 & $"$ & $"$ & granitic granofels clast & ze & Ksp & $125-250$ & furnace & $126 \pm 2$ \\
\hline
\end{tabular}

${ }^{\mathrm{a}} \mathrm{P} \#=$ sample number in the GNS Science Petrology Collection, NZMG = New Zealand Map Grid reference, fg = fine grained, epid = epidotized, $\mathrm{pr}-\mathrm{pu}=$ prehinite pumpellyite, $\mathrm{gs}-\mathrm{chl}=$ greenschist facies chlorite zone, $\mathrm{di}=$ diagenetic, $\mathrm{ze}=$ zeolite facies, $\mathrm{Ksp}=$ potassium feldspar, mica $=$ white mica, Trias $=$ Triassic. Oretian and Otapirian are local New Zealand Triassic stages. Ar-Ar ages in rightmost column are mean grain ages for laser data and total fusion ages for furnace data.

$>500 \mathrm{Ma}$, and three zircons have ages between 220 and $240 \mathrm{Ma}$ (C. J. Adams, personal communication, 2010); these features are typical of other Rakaia Terrane samples [Adams et al., 2007]. Pierces Gorge rocks are non-schistose, are downgrade of the prehnite-out isograd and downgrade of the recognized "isograd" at which detrital K-feldspar disappears [Bishop, 1972]. Textures of K-feldspars from biotite granite sample PG5 are shown in Figure 2a. Backscattered electron (BSE) images reveal $20-50 \mu \mathrm{m}$ perthitic intergrowths as well as fine stringers of plagioclase $<10 \mu \mathrm{m}$ wide and up to $50 \mu \mathrm{m}$ long. Thin sections show that most K-feldspar grains are clear and inclusion-free but some are cut by veins of prehnite (Figure 2a). Cold cathodoluminescence (CL) images show blue-purple luminescing areas of primary magmatic K-feldspar but also areas of secondary K-feldspar that luminesce a characteristic orange-yellow color due to microporosity and $\mathrm{Fe}$ activators [Finch and Walker, 1991; Leichmann et al., 2003; Lee et al., 2007]. This extensive patchy recrystallization revealed in the CL grain images is not obvious in the optical and BSE images.

\subsection{Caples Terrane}

[6] Caples Terrane is a sandstone and mudstone-dominated terrane that lies between the Rakaia Terrane and the Livingstone Fault. A number of discontinuous groups and formations are recognized with distinct geographic limits, lithofacies and petrofacies [Turnbull, 1979, 2000]. Caples rocks are tectonically imbricated, like the Rakaia Terrane, and are interpreted to have formed in the rearward part of the Jurassic-Cretaceous accretionary wedge (Figure 1). In contrast to the Rakaia Terrane, typical sandstones are volcaniclastic feldspathic litharenites of average andesitic bulk composition, with more rhyodacitic and potassic compositions particularly common along the Otago coast [Coombs et al., 2000]. Triassic radiolarians and trace fossils are known from near Quoin Point (Figure 1) [Campbell and Campbell, 1970; Ito et al., 2000] and recent detrital zircon dating also suggests that Caples greywackes are dominantly Triassic with the youngest significant detrital zircon peak in a Quoin Point sandstone being $221 \mathrm{Ma}$ [Adams et al., 2007, 2009]. Conglomerates are rare in the Caples Terrane but, for this study, we extracted K-feldspar from a granite clast in a weakly schistose conglomerate at Quoin Point and from a gritty sandstone inland near Clydevale [Becker, 1973].

[7] Metamorphic grade in the Caples Terrane is prehnitepumpellyite facies in unfoliated sequences near the Livingstone Fault. Near our Quoin Point sample locality, Fagereng and Cooper [2010] have estimated peak metamorphic conditions to have been $250-300{ }^{\circ} \mathrm{C}$ at $4.0-5.5 \mathrm{~Kb}$. This is in agreement with Frey et al.'s [1991] temperature range for prehnite-pumpellyite facies of $175-280^{\circ} \mathrm{C}$. Textures of $\mathrm{K}$-feldspars from schistose granite clast QP1 are shown in Figure $2 \mathrm{~b}$. They include $>100 \mu \mathrm{m}$ granophyric intergrowths with quartz, as well as irregularly shaped and oriented blebs and stringers of plagioclase up to $10 \mu \mathrm{m}$ in size. Some very fine $(<5 \mu \mathrm{m})$ stringers and grains of plagioclase are present and the latter appear to be associated with areas of secondary, yellow luminescing, K-feldspar. Despite the metamorphic grade, the K-feldspar contains no inclusions of reaction products such as sericite or stilpnomelane.

\subsection{Otago Schist}

[8] Both Rakaia and Caples Terranes are overprinted by the Otago Schist (technically, Caples sites QP and CV above are just within the mapped limits of schistosity). Metamorphic grade increases from regional prehnite-pumpellyite facies on the schist flanks, through lawsonite-albite-chlorite, pumpellyite-actinolite to greenschist facies (garnet-biotitealbite zone) along the Otago Antiform axis (Figure 1) [Mortimer, 2000]. On the basis of existing $\mathrm{K}-\mathrm{Ar}$ and $\mathrm{Ar}-\mathrm{Ar}$ dating, the age of prograde metamorphism is considered to be broadly Jurassic with exhumation and cooling extending 

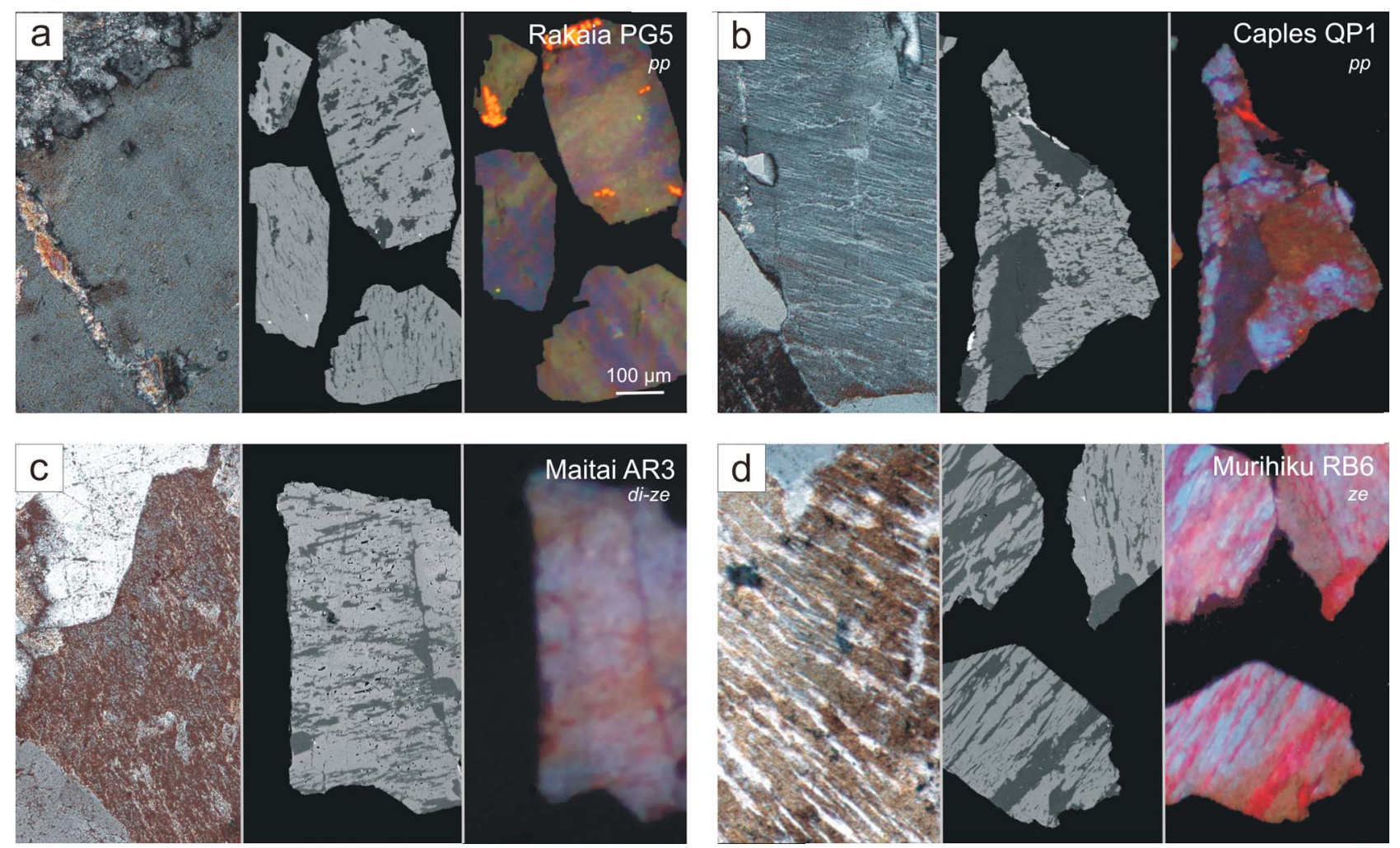

Figure 2. Each set of images shows representative (left) cross-polarized light thin section images, (middle) backscattered electron (BSE) images, and (right) cold cathodoluminescence (CL) images of K-feldspar grains. (a) PG5 granite clast cut by prehnite vein from Rakaia prehnite-pumpellyite (pp) facies conglomerate. (b) QP1 (P64145) granite clast from Caples prehnite-pumpellyite (pp) facies conglomerate. (c) AR3 pink granite clast from lower zeolite facies (di-ze) Maitai conglomerate. (d) RB6 biotite granite clast from upper zeolite facies (ze) Murihiku conglomerate. All images are the same scale. In the BSE images K-feldspar is light gray, plagioclase medium gray and quartz dark gray. In the CL images primary igneous K-feldspar luminesces with blue-purple colors and secondary (micropore-rich) K-feldspar with orange-yellow colors [Finch and Walker, 1991; Leichmann et al., 2003; Lee et al., 2007].

into the Early Cretaceous (see discussion below). On the low grade schist flanks, shallow to steep $\mathrm{S}_{1}$ foliation is overprinted on Rakaia and Caples bedding; in the higher grade schist core, shallow $\mathrm{S}_{2}$ fabrics dominate (Figure 1).

[9] Our three Otago Schist white mica sample localities are in the chlorite zone of the greenschist facies rocks of the Caples Terrane. Here, a prominent $S_{1}$ foliation is the only fabric (defined by micas of approximately $10 \mu \mathrm{m}$ in thickness and $100 \mu \mathrm{m}$ perpendicular to c-axis). In contrast to the Rakaia Terrane, detrital white mica is rare to absent in Caples sandstones; petrographic observations confirm that detrital mica is entirely absent from our three samples. Mortimer [2000] estimated peak temperatures in the garnetbiotite-albite zone of the Otago Schist (just north and up-grade of our three samples) to be $330-400^{\circ} \mathrm{C}$.

\subsection{Maitai Terrane}

[10] The Permian-Triassic Maitai Terrane is divided into three main stratigraphic groups: Dun Mountain Ultramafics, Livingstone Volcanics and Maitai [Turnbull and Allibone, 2003]. The Dun Mountain Ultramafics and Livingstone Volcanics constitute the Dun Mountain Ophiolite Belt and consist of gabbro, peridotite, serpentinite and serpentinitematrix melange, and of spilitic and keratophyric volcanics, volcanic breccia and sandstone, and minor 275-285 Ma diorite, tonalite and plagiogranite respectively [Kimbrough et al., 1992; Turnbull and Allibone, 2003]. The Maitai Group is well stratified, more than $5000 \mathrm{~m}$ thick and consists of several laterally continuous sandstone, siltstone and limestone formations with minor conglomerate [see Turnbull, 2000, Figure 20]. Most Maitai sandstones are lithic feldsarenites. Structurally, most of the Maitai Group, including near our inland sample site, is steeply dipping and southwest facing. Our inland Maitai sample site (AR) is a zeolite facies Greville Formation (Early Triassic) conglomerate [Cawood, 1987] from which Kimbrough et al. [1992] obtained a $265 \mathrm{Ma}$ U-Pb age on a granite clast. K-feldspar textures from granite clast AR3 are shown in Figure 2c; the K-feldspars from this rock are noticeably more turbid than most others in our sample set; broadly aligned igneous perthitic exsolution lamellae range in size from 5 to $50 \mu \mathrm{m}$. Most of the feldspar grain in Figure 2c is blue- rather than yellow-luminescent, implying less secondary alteration compared with K-feldspars from other terranes. 
[11] An Early to Middle Triassic sequence of wellstratified rocks, the Willsher Group, is exposed on the Otago coast (near our locality RH in Figure 1) [Waddell, 1969; Campbell et al., 2003; Turnbull and Allibone, 2003]. These rocks are of much lower metamorphic grade than the nearby Caples and Murihiku strata and contain the metamorphic index minerals analcime and heulandite. Based on spore color index, clay crystallinity and presence of analcime, Campbell et al. [2003] interpret maximum temperatures of $80-120^{\circ} \mathrm{C}$ for the coast section. This and other features have led Campbell et al. [2003] to consider them as being a distinct tectonostratigraphic terrane but, given their overall structural position between Caples and Murihiku Terranes, they are here considered part of the Maitai Terrane.

\subsection{Murihiku Terrane}

[12] The Murihiku Terrane comprises a 9-13 km thick, mainly marine, volcaniclastic, fossiliferous and well-stratified succession of Late Permian to Late Jurassic shelf and upper slope sandstones and siltstones [Turnbull and Allibone, 2003, and references therein]. Tuffs are common. The Murihiku Supergroup constitutes the most coherent stratigraphic entity within the basement rocks of New Zealand. Metamorphic grade is zeolite facies with stilbite, heulandite and laumontite zones reflecting different burial depths and dehydration reactions [Coombs, 1954; Boles, 1991]. Frey et al.'s [1991] temperatures for the upper limit of zeolite facies are $150-260^{\circ} \mathrm{C}$.

[13] In Southland, Murihiku Terrane is deformed into an asymmetrical regional syncline with a subvertical northern limb and a subhorizontal southern limb (Figure 1). Our two sample sites were in the Late Triassic Taringatura Group, on the northern limb of the syncline [Wood, 1956; Campbell, 1987]. The RB sample site is slightly older than the GO sample site (New Zealand Oretian stage versus Otapirian stage). K-feldspar textures from granite clast RB6 are shown in Figure 2d; grains show well aligned igneous perthitic exsolution lamellae ranging in size from 10 to $50 \mu \mathrm{m}$. Textural evidence of recrystallization is seen in the CL image as yellow-luminescent areas of K-feldspar; as with sample QP1 these seem to be associated with very fine $<5 \mu \mathrm{m}$ plagioclase exsolution lamellae and/or inclusions.

\subsection{Architecture of the Mesozoic Gondwana Margin}

[14] Most of the tectonic components of a convergent margin are seen in the cross-section shown in Figure 1: a Mesozoic magmatic arc (Median Batholith [Mortimer et al., 1999]), an accretionary wedge (Otago Schist and constituent Rakaia and Caples Terranes) and, between the arc and wedge, a region of forearc terranes comprising the Brook Street, Murihiku and Maitai Terranes. However, the precise paleogeographic relationships between, and timing of assembly of, these elements is poorly known. They were probably amalgamated by the end of the Early Cretaceous (c. $100 \mathrm{Ma}$ ) at the close of a cycle of long-lived Gondwana subduction which, by c. $85 \mathrm{Ma}$, had given way to widespread passive margin sedimentation [Bradshaw, 1989; Mortimer, 2004].

[15] There still could be major $(>1 \mathrm{~km})$ Jurassic to Early Cretaceous strike- and/or dip-slip movement on terranebounding faults of Figure 1. Of these, the Livingstone Fault is arguably the most significant as its footwall comprises mantle peridotites of the Dun Mountain Ophiolite Belt. Field observations and gravity interpretations confirm that the
Livingstone Fault presently dips under the Otago Schist (Figure 1) [Wood, 1956; Mortimer et al., 2002].

\section{Geochronology and Thermochronology}

\subsection{Methods}

[16] Location and rock type information for all 16 samples is shown in Table 1. K-feldspar samples were selected for mineral separation after petrographic examination of thin sections of a much larger number of samples stained for K-feldspar (Figure 2). White mica samples were selected after petrographic examination to ensure the presence of just one penetrative $S_{1}$ foliation, and the absence of detrital mica.

[17] All hand-picked mineral separates, except those from the Rakaia Terrane, were irradiated for $288 \mathrm{~h}$ in facilities X33 or X34 of the Australian Nuclear Science and Technology Organization HIFAR reactor, Lucas Heights, New South Wales. The sample can was inverted during the irradiation to minimize the effect of the large neutron fluence gradient and a cadmium liner was used to minimize interference from thermal neutrons. Biotite standard GA1550 (with $\mathrm{K} / \mathrm{Ar}$ age of $98.8 \mathrm{Ma}$ [McDougall and Roksandic, 1974; Renne et al., 1998]) was used as the fluence monitor. All samples were subsequently analyzed at the Australian National University using a VG3600 gas source mass spectrometer for the K-feldspar samples (sensitivity for argon c. Four $\times 10^{-17} \mathrm{~mol} / \mathrm{mV}$ ) and a VG1200 gas source mass spectrometer for the white mica samples (sensitivity for argon c. Eight $\times 10^{-17} \mathrm{~mol} / \mathrm{mV}$ ). During step heating experiments sample temperature was monitored using a thermocouple at the base of a tantalum crucible within a double-vacuum resistance furnace. The schedules of heating times and temperatures for each sample are listed in the raw data tables.

[18] Additional samples from the Rakaia Terrane on the north side of the Otago Schist were obtained later in the study in order to supplement the results from the furnace K-feldspar analyses of Caples, Maitai and Murihiku samples. These were not able to be analyzed by the same (furnace) method and a laser fusion method was used instead. K-feldspars from the Rakaia Terrane were irradiated for $50 \mathrm{~h}$ in position $5 \mathrm{C}$ of the McMaster University Nuclear Reactor, Hamilton, Canada. Irradiation parameters were again determined using fluence monitor GA1550. The three Rakaia Terrane K-feldspar samples were analyzed at the University of Melbourne. Single K-feldspar grains were analyzed by a single-step laser fusion, using a defocused Spectron Nd-YAG laser; between 25 and 29 grains were analyzed for each sample. After fusion, the gas released was exposed to two SAES NP10 getters for $\sim 12 \mathrm{~min}$ to remove all active gases. The isotopic composition of the purified argon gas was analyzed using a VG5400 gas source mass spectrometer equipped with a Daly detector (sensitivity for argon c. $2.2 \times 10^{-17} \mathrm{~mol} / \mathrm{mV}$ ). Corrections for argon produced by interactions of neutrons with $\mathrm{K}$ and $\mathrm{Ca}$ were made [Tetley et al., 1980] and the ${ }^{40} \mathrm{~K}$ abundance and decay constants are taken from values recommended by the International Union of Geological Sciences Subcommission on Geochronology [Steiger and Jaeger, 1977].

[19] All samples have been cataloged in the GNS Petrology Collection. Sample details can be obtained from the online PETLAB database at http://pet.gns.cri.nz, querying 

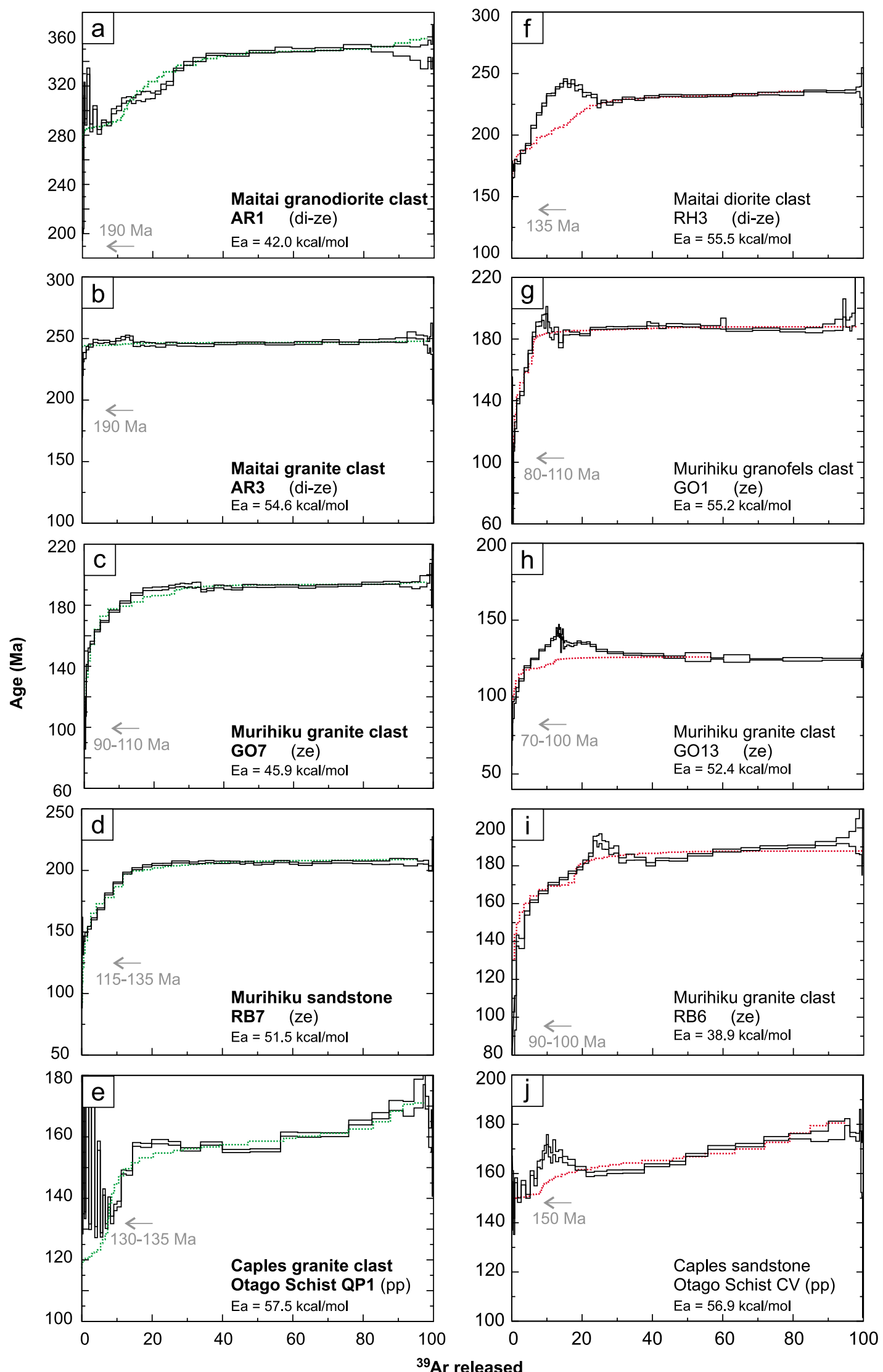

Figure 3 

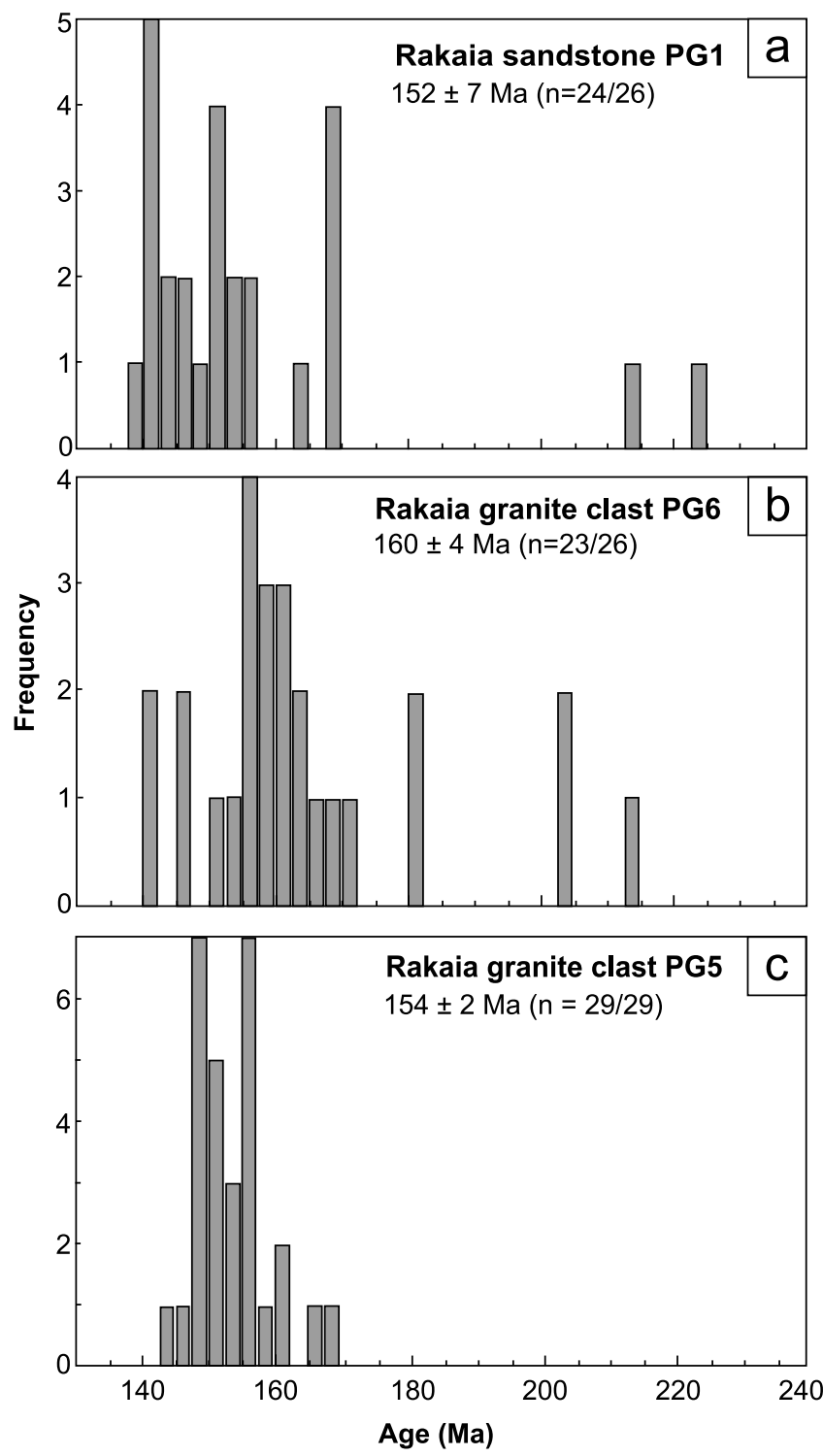

Figure 4. Age histograms for individual prehnite-pumpellyite facies Rakaia K-feldspar samples analyzed by single grain ${ }^{40} \mathrm{Ar} /{ }^{39} \mathrm{Ar}$ laser fusion: (a) sandstone PG1, (b) granite clast PG6, and (c) granite clast PG5.

by $\mathrm{P}$ number. Full analytical data, Arrhenius plots and thermal histories derived from multidiffusion domain (MDD) models are available in the auxiliary material. ${ }^{1}$

\subsection{Results}

\subsubsection{K-Feldspars}

[20] Age spectra for the ten K-feldspars analyzed by furnace step-heating are shown in Figure 3. They exhibit a

\footnotetext{
${ }^{1}$ Auxiliary materials are available in the HTML. doi:10.1029/ 2011TC003057.
}

variety of spectral patterns: some climb more or less monotonically, some have small humps in the intermediate gas release, some act erratically in the earliest release and some have remarkably uniform plateau segments. Maitai granodiorite and granite clasts AR1 and AR3 (Figures 3a and 3b), and Murihiku granite clast GO7 and sandstone bed RB7 (Figures $3 \mathrm{c}$ and $3 \mathrm{~d}$ ) essentially show monotonically increasing ages that approach plateau-like maxima by $20-30 \%$ of the gas release (by "plateau-like" we mean qualitatively flat on the age spectrum diagrams). The age spectrum of sample QP1, a granite clast in the Caples Terrane, also shows a similar pattern but the age spectrum is complicated by evidence for excess argon in the first $10 \%$ of gas released as indicated by the large difference in the age of isothermal duplicate steps (Figure 3e).

[21] In contrast, granitoid clasts GO1, GO13, RH3, RB6 and sandstone bed $\mathrm{CV}$ (which are from the same terranes and metamorphic grades as the above samples) exhibit, to varying degrees, age spectra which rise to a maximum age at $10-30 \%$ of the gas release, fall to younger ages and then rise in age again in the higher temperature steps, either climbing continuously or forming approximate plateaus (Figures $3 \mathrm{f}-3 \mathrm{j}$ ). In all cases the drop in age, into the saddle point, is about 10-20 million years. This type of intermediate age maximum pattern is well documented in the literature [e.g., Lovera et al., 2002; McDougall and Harrison, 1999] and generally characterizes samples that have experienced lowtemperature recrystallization [e.g., Warnock and van der Kamp, 1999], resulting in at least partial loss of accumulated radiogenic argon.

[22] Data for each of the three Rakaia Terrane K-feldspar samples analyzed by single grain laser fusion are shown as histograms in Figure 4. The spread of ages recorded by all three samples is very similar, with the majority of grains in each sample yielding ages in the range 150-160 Ma. However, there are some differences. PG1 is from a sandstone bed and the detrital K-feldspars show a larger range of ages, including two (more Ar-retentive?) grains which yield Late Triassic ages (Figure 4a). Fine grained granite clast PG6 also yields two grains of Late Triassic age (Figure 4b) while granite clast PG5 records only Middle-Late Jurassic ages (Figure $4 \mathrm{c}$ ). We have chosen to treat the single grain laser fusion data with robust statistics [e.g., Hampel et al., 1986] using the method outlined by Powell et al. [2002]. We note that the error on the age of each individual grain is small when compared to the overall spread of the ages. Thus, if the data have age significance, a robust estimator (tanh) can be used to calculate a mean age with an uncertainty based on the scatter of the data rather than the analytical uncertainties. In this approach, data lying significantly away from the main population are accounted for statistically. In this case, the robust statistical approach effectively excludes the outlier Triassic data and yields an age of $152 \pm 7 \mathrm{Ma}$ for the detrital K-feldspars from sandstone PG1 (two sigma error quoted for all age estimates); an age of $160 \pm 4$ Ma for K-feldspars

Figure 3. Individual ${ }^{40} \mathrm{Ar} /{ }^{39} \mathrm{Ar} \mathrm{K}$-feldspar furnace step-heating spectra from Maitai, Murihiku and Caples Terranes. (a-e) Samples that are ostensibly amenable to multi diffusion domain (MDD) modeling. ( $f-j$ ) Samples with hump-shaped spectra that clearly are not amenable to MDD modeling. Dashed lines are modeled fits to the data. Age range of first gas release steps shown in gray type. Samples are arranged in order of approximate increasing metamorphic grade of host rocks down the page. di-ze $=$ diagenesis to zeolite facies, $z e=$ zeolite facies, $p p=$ prehnite-pumpellyite facies . 
from clast PG6; and an age of $154 \pm 2$ Ma for the K-feldspars from clast PG5 (Figure 4). An aggregate of data from all three samples yields a weighted mean age of $154 \pm 2 \mathrm{Ma}$.

\subsubsection{White Micas}

[23] The $\mathrm{S}_{1}$ white micas from the three sample sites from the Caples Terrane of the Otago Schist give essentially
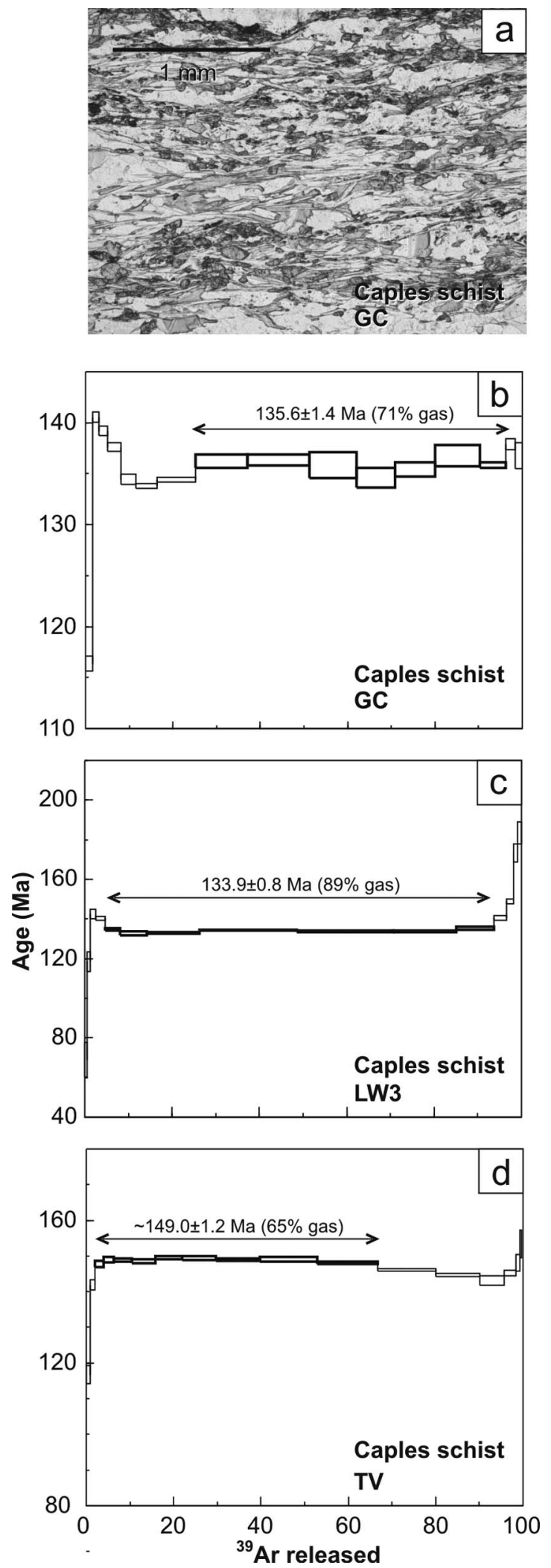

similar age spectra (Figure 5). Our GC sample is from the same site as whole rock sample DG90-77B of Gray and Foster [2004], which yielded an argon isochron age of $134.3 \pm 1.4 \mathrm{Ma}$. White mica from our GC sample, (Figures 5a and 5b), yields a plateau-like section over $71 \%$ of gas release with an age of $135.6 \pm 1.4 \mathrm{Ma}$ (all ages quoted are two sigma). Both samples from this site thus have ${ }^{40} \mathrm{Ar}-{ }^{39} \mathrm{Ar}$ ages within error of each other. A white mica concentrate from a Caples schist at site LW3 has a plateau-like section of $133.9 \pm 0.8 \mathrm{Ma}$ over $89 \%$ of gas release (Figure $5 \mathrm{c}$ ). A significantly older white mica was concentrated and analyzed from the Caples schist at Teviot (sample TV, Figure 5d). This sample yields a somewhat discordant age spectrum with a plateau-like section at $149.0 \pm 1.2 \mathrm{Ma}$ in the early and middle gas release (c. $65 \%$ of the gas), followed by ages that decline to as low as $143 \mathrm{Ma}$. Our results agree with the map-scale trend of ages shown by earlier workers [e.g., Nishimura et al., 2000; Little et al., 1999; Gray and Foster, 2004; Mortimer, 2003] in which $\mathrm{K}-\mathrm{Ar}$ and ${ }^{40} \mathrm{Ar} /{ }^{39} \mathrm{Ar}$ ages in the Otago Schist get younger with increasing structural depth and metamorphic grade.

\subsection{Interpretation of K-Feldspar ${ }^{40} \mathrm{Ar} /{ }^{39} \mathrm{Ar}$ Ages}

3.3.1. General Comments

[24] Figure 6 shows the relationship between the measured age spectra of the K-feldspar samples and the known stratigraphic age of the sediments in which they are contained. In most cases the plateau-like age is younger than the known stratigraphic age, particularly for samples metamorphosed to the highest grade (prehnite-pumpellyite facies). None of the K-feldspar grains in our sample set show any clear textural evidence for metamorphic adularia (Figure 2). In general we attach meaning to the minimum ages and to the plateau-like ages of the argon spectra. A separate assessment of the applicability of quantitative multidiffusion domain (MDD) models [Lovera et al., 1989; Richter et al., 1991] is given in section 4.1.

\subsubsection{Rakaia Terrane}

[25] As noted in Section 3.2.1 above, the single grain laser fusion ages of K-feldspars from granite clasts and a bulk sandstone at the same location in the Rakaia Terrane give a weighted mean of $154 \pm 2 \mathrm{Ma}$, significantly younger than the Triassic age of deposition and/or diagenesis and c. 90 m.y. younger than the youngest detrital zircon peak. The most obvious interpretation of these data is that they reflect a major reheating or recrystallization event at c. $155 \mathrm{Ma}$ and we suggest that this pooled age was acquired during prehnitepumpellyite facies regional metamorphism of this part of the Rakaia Terrane. The $>175 \mathrm{Ma}$ ages of 4 of the $81 \mathrm{~K}$-feldspar grains analyzed indicates that some more retentive and/or unrecrystallized $\mathrm{K}$-feldspar grains still preserve a partial record of their source area ages [Adams et al., 2007].

\footnotetext{
Figure 5. (a) Plane-polarized light thin section image of greenschist facies Caples psammitic schist GC, showing undulating but single and penetrative $S_{1}$ mica fabric. Mineral assemblage is quartz + albite + white mica (pale gray grains) + chlorite + actinolite (medium gray) + epidote + titanite (dark gray). (b-d) ${ }^{40} \mathrm{Ar} /{ }^{39} \mathrm{Ar}$ furnace step-heating spectra of white mica from samples GC, LW3 and TV, all from the greenschist facies Caples Terrane part of the Otago Schist.
} 


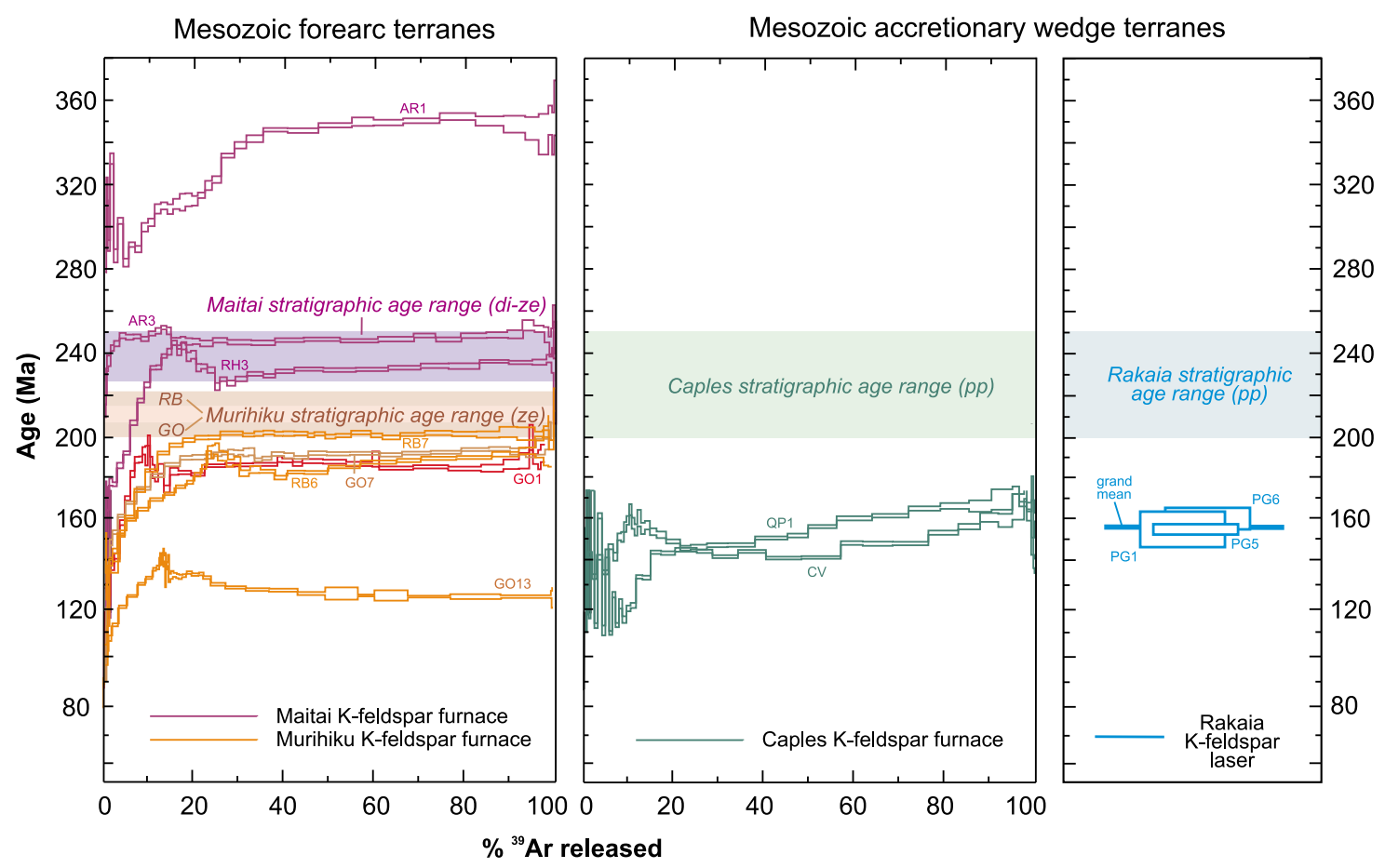

Figure 6. Stacked K-feldspar age spectra from Maitai, Murihiku and Caples Terranes, and K-feldspar laser mean ages from Rakaia Terrane summarizing relationship between argon-argon ages, stratigraphic ages and metamorphic grades of the Mesozoic accretionary wedge and forearc basin terranes. Colors match units in Figure 1.

\subsubsection{Caples Terrane}

[26] K-feldspars from Caples Terrane granite clast QP1 and sandstone $\mathrm{CV}$ record some of the youngest range of furnace ages of our sample set, with ${ }^{40} \mathrm{Ar} /{ }^{39} \mathrm{Ar}$ ages being significantly younger than both the Triassic stratigraphic ages of the sediments they are contained within and the 221 Ma detrital zircon peak (Table 1 and Figure 6). The age spectrum of QP1 K-feldspar shows a maximum age of only 170-180 Ma (Figure 3e), suggesting that the sample was completely outgassed of all radiogenic argon prior to, or at, this time. Most ages of the central part of the degassing spectrum are between 150 and $170 \mathrm{Ma}$ with final closure to argon loss at, or more recently than, 120-130 Ma. Although simple MDD models can produce acceptable fits to the laboratory age spectrum (Figure 3; also see auxiliary material) they demand temperatures $>350^{\circ} \mathrm{C}$ at, or until, $180 \mathrm{Ma}$. Such temperatures are much - and unreasonably - higher than the prehnite-pumpellyite metamorphic grade and estimated peak temperature of the samples. As such we interpret the measured ages as the result of recrystallization and/or degassing related to fluid flow, diagenetic processes [e.g., Harlavan and Sandler, 2010] and/or metamorphism at around this time, such that the MDD model cannot be usefully applied [Harrison et al., 2010]. The observed CL K-feldspar textures (Figure 2b) confirm that recrystallization has taken place.

[27] The age spectrum of K-feldspars from bulk sandstone sample CV is broadly similar to sample QP1 in the middle and late gas release, and indicates that the K-feldspars in both low-grade Caples rocks were heated and/or recrystallized sometime around $180 \mathrm{Ma}$. Like QP1, the monotonically increasing portion of the age spectrum between 160 and 180 Ma possibly suggests a period of slow cooling in this interval (Figure 3j). Final closure to argon loss in sample $\mathrm{CV}$ occurred some time more recently than $160 \mathrm{Ma}$; further information on the thermal history is obscured by the presence of apparent excess argon contamination in the first $20 \%$ of the gas release. Unfortunately, correction of the apparent excess argon in the early released gas of both Caples samples following the method of Harrison et al. [1994] was unsuccessful.

[28] In summary, we interpret both Caples samples to show evidence of some heating and/or recrystallization at c. 180-160 Ma, much later than the depositional/diagenetic age. This is in good agreement with the known geological history and provides useful corroboration of Middle Jurassic prograde metamorphism previously inferred only from agedistance profiles of K-Ar mica ages [Adams and Robinson, 1993; Nishimura et al., 2000].

\subsubsection{Maitai Terrane}

[29] K-feldspars RH3, AR1 and AR3 from granitoid clasts in the diagenetic to zeolite facies Maitai Terrane record a range of ages distinctly older than K-feldspars from all other terranes in this study (Figure 6). K-feldspar from granodiorite clast AR1 records ages much older than the stratigraphic age of the sediment, and this is interpreted to be a quantitative record of cooling of a Devonian-Carboniferous granite in its source region. AR1 exhibits a monotonically increasing age spectrum, from the youngest ages of around $280 \mathrm{Ma}$ to a plateau segment of around $355 \mathrm{Ma}$ (Figure 3a). These ages suggest relatively slow cooling from around $360 \mathrm{Ma}$, with accelerated cooling from 300 Ma until final closure to argon loss at around $280 \mathrm{Ma}$. The $360 \mathrm{Ma}$ cooling age matches published Maitai Terrane detrital zircon U-Pb age spectra 
which show peaks in the range 355-400 Ma [Adams et al., 2002]. Ironically, and interestingly from the point of view of understanding the applicability of the MDD modeling, sample AR1 is visibly the most turbid and altered of our entire sample set, with pervasive secondary epidote, chlorite and sericite present throughout the granodiorite clast.

[30] In contrast, K-feldspars from granite clasts AR3 and RH3 record ages that overlap the depositional age of the Early Triassic strata in which they are found (Figure 6). AR3 records a very narrow range of ages and the age spectrum is characterized by a plateau segment of approximately $250 \mathrm{Ma}$ that encompasses almost $90 \%$ of the gas released (Figure $3 b$ ). These observations indicate very rapid cooling from high temperature at around $250 \mathrm{Ma}$; consistent with a 260-265 Ma U-Pb zircon peak of Maitai detrital zircons [Adams et al., 2002] and possibly with the 265 Ma granite of Kimbrough et al. [1992] from the same locality. The youngest released gas is around $230 \mathrm{Ma}$, suggesting some degree of argon loss associated with early diagenesis.

[31] The age spectrum of RH3 is less straightforward, with the intermediate age maximum suggesting recrystallization following deposition (Figure 3f). The plateau-like segment implies rapid cooling around $240-230 \mathrm{Ma}$, which is probably also a source area signal. The youngest released gas around $135 \mathrm{Ma}$ is consistent with argon loss due to reheating and/or recrystallization at around that time.

\subsubsection{Murihiku Terrane}

[32] K-feldspars from samples GO1, GO7 and GO13 are from three separate conglomerate clasts at the same Late Triassic (200-206 Ma) outcrop and should have shared the same diagenetic and metamorphic history. GO1 and GO7 show similar age spectra with distinct plateau-like sections at $187 \mathrm{Ma}$ and 193 Ma respectively; these ages are c. 10-15 m.y. younger than the depositional age. The youngest released gas is $<100 \mathrm{Ma}$ in all three cases, indicating final closure to argon loss around this time, possibly related to late extension or fluid movement within the sequence [e.g., Boles, 1991]. A simple MDD model of GO7 produces an acceptable fit to the laboratory age spectrum (Figure $3 \mathrm{c}$ and auxiliary material) but demands temperatures $>350^{\circ} \mathrm{C}$ almost immediately after deposition of the conglomerates. Such temperatures are even less feasible for the Murihiku Terrane than for the Caples Terrane as metamorphic grade is only zeolite facies and c. Four km thickness of sediments continued to be deposited in the Murihiku Terrane on top of the conglomerates at Gore through to at least c. $160 \mathrm{Ma}$ [Wood, 1956]. Two alternative interpretations are again possible: (1) the upper limit of the closure temperature to argon loss is much lower than $350^{\circ} \mathrm{C}$ such that the time of onset of metamorphism in the Triassic strata of the Murihiku Terrane was c. $190 \mathrm{Ma}$; (2) more likely the measured ages are the result of recrystallization and fluid flow associated with diagenesis and/or early metamorphism at around this time and that the pronounced age gradients in the first $20 \%$ of the gas release reflect further partial argon loss during later metamorphism (sometime between 80 and $100 \mathrm{Ma}$ ).

[33] In contrast to the igneous-textured $\mathrm{GO} 1$ and $\mathrm{GO} 7$ clasts, the granofelsic clast GO13 exhibits a much younger range of ages with a quasi-plateau segment at 125-135 Ma. The pronounced hump-shape of this age spectrum provides evidence for recrystallization, and we prefer to interpret the age spectrum of this sample in the context of a major, but spatially variable (selective on a clast-by-clast basis), recrystallization event at 125-135 Ma.

[34] K-feldspars RB6 and RB7 are from 215 to $222 \mathrm{Ma}$ conglomerate outcrops at Roaring Bay in the eastern Murihiku Terrane. K-feldspar from bulk sandstone bed sample RB7 has a maximum age of about $207 \mathrm{Ma}$, again some 10-15 m.y. younger than the well-determined stratigraphic age. As above, a simple thermal model can produce an acceptable fit to the laboratory age spectrum for RB7 but demands unreasonably high temperatures. Like the Gore conglomerate samples, we prefer to interpret the Roaring Bay age spectra as reflecting argon loss and recrystallization during diagenesis and/or metamorphism. The shape of the age spectrum and the youngest recorded ages of around 115-135 Ma suggest that final closure to argon loss occurred around this time.

[35] The age spectrum of K-feldspar from granite clast RB6 shows some evidence for recrystallization in the form of an intermediate hump, but rises to a plateau around $190 \mathrm{Ma}$ (again, a little younger than the stratigraphic age). Final closure of RB6 took place after $130 \mathrm{Ma}$, again pointing to a recrystallization or thermal event possibly as young as 90-100 Ma.

\subsection{Interpretation of Otago Schist White Mica ${ }^{40} \mathrm{Ar} /{ }^{39} \mathrm{Ar}$ Ages}

[36] For the Caples Terrane on the low grade Otago Schist flanks (Figure 1, i.e., away from the antiform axis), Gray and Foster [2004] made a case that ${ }^{40} \mathrm{Ar} /{ }^{39} \mathrm{Ar}$ ages of white micas probably record crystallization ages, as the peak temperature is too low to allow significant diffusive loss of argon. We agree with their interpretation for the following reasons: 1) the age spectra from the flanks, including our data from the southern flank, do not exhibit strong age gradients of the kind that are often associated with reheating at a time subsequent to crystallization [Dunlap and Wysoczanski, 2002; Dunlap, 2003]; 2) the young ages of the early gas release generally only comprise a minor percentage of the total; 3) the general absence of strongly rising (staircase) spectra [Dunlap, 1997; Dunlap et al., 1997], as well as 4) microstructural observations on our samples that indicate no contamination by an older detrital white mica component; 5) we attribute the elevated ages in the late gas releases in sample LW3 to a furnace memory effect. Thus, we conclude that our white mica concentrates from LW3, TV and GC are likely to record crystallization (growth) ages.

[37] One important caveat in the Gray and Foster [2004] Ar-Ar data set is that virtually all ages in the $150-160 \mathrm{Ma}$ range are whole rock data which, according to Dunlap [1997] can give unrealistically elevated ages due to the likelihood of excess argon trapped in fluid inclusions in quartz. Thus our c. 150 Ma plateau-like age for white mica at Teviot (TV) may represent the oldest pure white mica crystallization age yet obtained from the Otago Schist.

\section{Discussion}

\subsection{K-Feldspars: Recrystallization Versus Cooling}

[38] The interpretation of K-feldspar age spectra has been the subject of considerable discussion in the literature over 
the past two decades. Several descriptions of argon diffusion have been developed. The quantitative multidiffusion domain (MDD) model of Lovera et al. [1989] and Richter et al. [1991] has received considerable attention. The model assumes that the retention of argon in nature and the loss of argon in the laboratory are controlled only by thermally activated volume diffusion, described by the Arrhenius equation. The model attests that ${ }^{40} \mathrm{Ar} /{ }^{39} \mathrm{Ar}$ age gradients in K-feldspars are the result of variable argon retention by different-sized diffusion domains which give a range in closure temperature and which can be inverted to yield continuous cooling histories. As a result the model has been applied to various problems in tectonics and structural geology. But the assumption of volume diffusion has been questioned by Lee [1995]. Moreover, Parsons et al. [1999] suggest the assumption of volume diffusion made by the MDD model does not apply because recrystallization processes that result in the redistribution of argon can occur at a variety of temperatures, including at near-surface conditions. Lovera et al. [2002] also note that the MDD method yields good results for only a proportion of K-feldspars that show well-behaved age spectra and specifically for those which show a good relationship between the age spectra and the calculated domain distribution.

[39] McLaren et al. [2007] suggest the MDD model and the recrystallization model are end-members of what is a wide range of possible argon-loss behavior in natural K-feldspars. They advocate using simple microstructural observations obtained from SEM as a predictor of the suitability of grains for detailed analysis (cf. Figure 2). We note that recrystallization is particularly a problem for K-feldspars which have experienced a complex geological history, and/or one involving multiple low-temperature events [e.g., Harrison et al., 2010]. The detrital K-feldspars in this study fall into this category.

[40] Of the K-feldspar samples analyzed here, all except those from the diagenetic to zeolite facies Maitai Terrane yield ages that are younger than the inferred stratigraphic ages of the enclosing metasedimentary rocks (Table 1 and Figure 6). These data imply that either: (1) metamorphic temperatures were $>350^{\circ} \mathrm{C}$, the generally accepted maximum closure temperature of K-feldspar to argon loss [Lovera et al., 2002] very soon after deposition, a suggestion inconsistent with the observed metamorphic grades of the samples; (2) the maximum $\mathrm{K}$-feldspar closure temperature is closer to $250^{\circ} \mathrm{C}$ in which case the quantitative retention of argon is the result of cooling following regional metamorphism; or (3) pervasive low-temperature recrystallization, associated with metamorphism, fluid-flow and/or early diagenesis, has impacted on the distribution of argon within individual grains. Regardless of whether interpretation (2) or (3) is most correct, our results suggest that inferences about quantitative cooling paths for our samples using the MDD method are not appropriate. However, the consistency of oldest and youngest ages from different K-feldspars here provides useful first-order thermal information that can be integrated with stratigraphic and tectonic data. Thus, ${ }^{40} \mathrm{Ar} /{ }^{39} \mathrm{Ar}$ analyses of $\mathrm{K}$-feldspars from low metamorphic grade rocks can be of use, provided interpretations are formed with regard for the textural and mineralogic characteristics of those mineral grains.

[41] ${ }^{40} \mathrm{Ar} /{ }^{39} \mathrm{Ar}$ ages have been shown to record the timing of growth of authigenic feldspar during diagenesis [Sherlock et al., 2005; Harlavan and Sandler, 2010] however the extent to which argon ages of pre-existing detrital K-feldspar grains are reset by diagenesis has not been well documented. In the case of our analyzed K-feldspars, it is not apparent that young ${ }^{40} \mathrm{Ar} /{ }^{39} \mathrm{Ar}$ ages originate specifically from authigenic overgrowths, however the CL images (Figure 2) confirm the composite (primary and secondary) nature of the analyzed K-feldspar grains, especially at higher host rock metamorphic grades (Figure 2).

[42] Small differences in the apparent timing of the Jurassic thermal and/or recrystallization event between samples from the same site are probably due at least in part to the different retentivities of the K-feldspars (Figure 3). For instance, variable retentivity between $\mathrm{GO} 1$ and $\mathrm{GO} 7$ is reflected in the slightly older ages recorded by GO7. In contrast, large variations between samples most likely reflect different response to post-metamorphic recrystallization (e.g., very young ages of the GO13 sample, compared with GO1 and GO7). Similarly, RB6 is younger than RB7 by about $20 \mathrm{~m}$.y, which must be at least partially the result of later recrystallization (supported by the hump shape of age spectrum RB6).

[43] A number of mechanisms that could result in the loss of accumulated radiogenic argon in K-feldspars have been noted by Parsons et al. [1999], and we refer to these mechanisms, here and above, collectively as "recrystallization." Although it is clear that partial or total recrystallization of K-feldspar can take place at temperatures of $20-200^{\circ} \mathrm{C}$, the precise temperature or temperature range at which certain mechanisms are active (replacement textures, for example) remains undocumented. The fact that many K-feldspar argon ages are slightly younger than the stratigraphic ages of their host lithologies, suggests that recrystallization, as well as new feldspar growth [Harlavan and Sandler, 2010], can be pervasive during diagenesis and low-grade metamorphic alteration [e.g., Leichmann et al., 2003].

[44] As mentioned above, the relationship between observed microtexture (Figure 2) and the extent of recrystallization and argon resetting (Figure 3 ) is not as clear in this data set as it was for those outlined by McLaren and Dunlap [2006] and McLaren et al. [2007]. However, the K-feldspars reported by these authors were contained within granitic rocks, rather than sedimentary rocks and it is possible that the additional effects of diagenesis mean that in sediments coarse microtextural observations (such as based on Figure 2) are not as reliable a predictor of the quality of thermochronological information available from a given sample as they are in igneous or metamorphic rocks. Further SEM or TEM data would be required to more fully evaluate the relationship between texture and argon age for these samples.

\subsection{Implications for Timing of Gondwana Margin Tectonic Events}

\subsubsection{Caples-Rakaia-Otago Schist Accretionary Wedge}

[45] Otago Schist tectonic models have changed from those emphasizing Jurassic terrane collision and crustal thickening [e.g., Mortimer, 1993] to those emphasizing Cretaceous extensional exhumation [e.g., Deckert et al., 2002; Forster and Lister, 2003; Gray and Foster, 2004] to those emphasizing an evolving accretionary wedge [e.g., Breeding and Ague, 2002; Rahl et al., 2011]. All are probably applicable, with convergent accretionary wedge structures preserved on the schist flanks and extensional fabrics in the core region of the Otago Antiform [Stallard and 


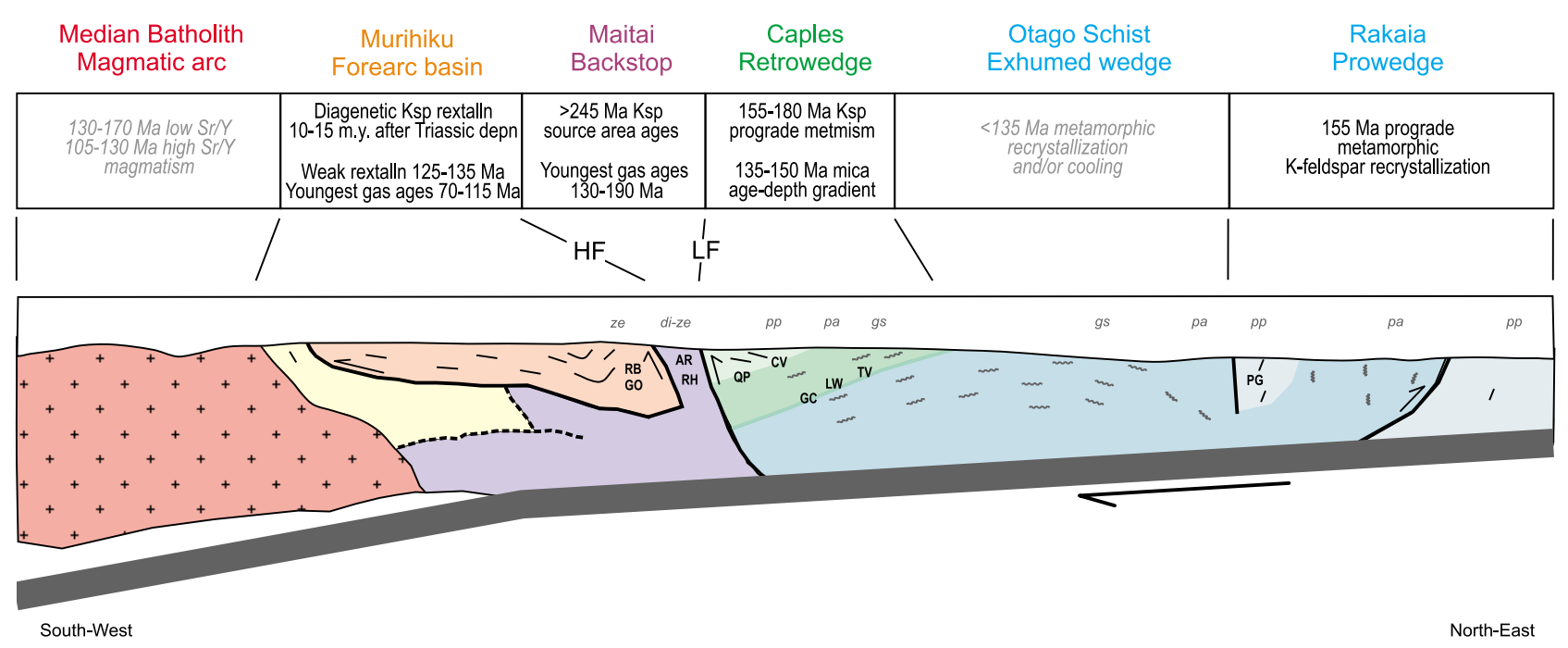

Figure 7. Summary of thermotectonic events in New Zealand's Mesozoic Median Batholith arc, Murihiku forearc basin, Maitai backstop, and Caples-Rakaia-Otago Schist accretionary wedge, summarizing results of this study (black text) and earlier studies of Little et al. [1999], Nishimura et al. [2000], Tulloch and Kimbrough [2003], Forster and Lister [2003], and Gray and Foster [2004] (gray italic text). Ages in the diagram are rounded to the nearest 5 m.y.

Shelley, 2004]. Different parts of the accretionary wedge (retrowedge, core, prowedge) might be expected to have different P-T-t histories.

[46] Nishimura et al. [2000], in a K-Ar study north and south of Quoin Point (Figure 1) interpreted a metamorphic peak at $175-155 \mathrm{Ma}$ followed by cooling to mica closure temperatures at 155-135 Ma. Little et al. [1999] interpreted a metamorphic peak at 170-180 Ma, with greenschist facies schist near the Caples-Rakaia boundary held at mid- to lower crustal depths until $135 \pm 5 \mathrm{Ma}$ after which it was exhumed at about $0.6-1.0 \mathrm{~mm} / \mathrm{yr}$ and affected by argon loss events from 120 to $75 \mathrm{Ma}$. Forster and Lister [2003] interpreted ductile shear zones in the schist core as having formed episodically from 122 to 109 Ma. Gray and Foster [2004] interpreted the main schist metamorphism and deformation to have occurred from 160 to $140 \mathrm{Ma}$, however they did not sample at the very lowest grades of schist [cf. Nishimura et al., 2000] so their interpreted time of metamorphism and deformation may not apply to inception at the true schist flanks. Gray and Foster [2004] interpreted shear zone deformation in the schist core to have taken place from $130 \mathrm{Ma}$ with post-wedge cooling and exhumation of the core along ductile shear zones in the interval 110-100 Ma.

[47] Our new results add K-feldspar to the range of geochronometers used to interpret the age of metamorphism in the Otago Schist. We interpret the data from samples QP1 and CV as evidence for prograde prehnite-pumpellyite facies metamorphic recrystallization between 155 and $180 \mathrm{Ma}$. They do not, however, allow us to refine any more precisely the timing of prograde metamorphism or changes in cooling rate, but are in broad agreement with the mica age interpretations of Nishimura et al. [2000]. The youngest gas ages in QP1 at 130 $135 \mathrm{Ma}$ could be a subtle retrowedge response to a major change in wedge dynamics, manifested by the initiation of ductile shear zones in the schist core region (Figure 7) [e.g., Forster and Lister, 2003; Gray and Foster, 2004].
[48] The $154 \pm 2 \mathrm{Ma}$ weighted mean of K-feldspar laser ages in the Rakaia Terrane is co-eval to slightly younger than the 155-180 Ma recrystallization ages at similar metamorphic grade on the Caples Terrane. In both terranes the new $\mathrm{K}$-feldspar ages lie within a range of existing $\mathrm{K}$-Ar schist ages that are high enough metamorphic grade not to be contaminated by older detrital white micas and low enough grade not to have been subjected to significant exhumation and cooling from depth [Mortimer, 2003]. Because both K-feldspar samples occupy similar structural positions on opposing schist flanks (Figure 1), this suggests that Middle Jurassic prehnitepumpellyite facies regional metamorphism in the accretionary wedge was either co-eval across the entire Caples and Rakaia terranes, or there could have been a slight trenchwardyounging of the age of inception of low grade metamorphism.

[49] Deeper in the Caples Terrane schist, our three white mica ages of $134 \mathrm{Ma}, 136 \mathrm{Ma}$ and $149 \mathrm{Ma}$ record mineral growth and/or cooling at deeper structural and metamorphic levels in the accretionary wedge than the QP location. Although textural and argon spectrum evidence suggests mineral growth rather than cooling ages, the fact that the samples fit on established age-depth curves for Otago Schist that span the interval 120-180 Ma [Little et al., 1999; Mortimer, 2003] means that an origin in an exhumed partial argon retention zone cannot entirely be ruled out.

\subsubsection{Maitai-Murihiku Wedge Backstop and Forearc Basin}

[50] Extraction of clear Jurassic-Cretaceous thermotectonic signals from the Maitai and Murihiku K-feldspars is more difficult than with the higher metamorphic grade Caples and Rakaia samples. The large range in retentivity between clasts from the same outcrop, and the 10-15 m.y. difference between depositional age and plateau-like segments of many argon spectra, are especially puzzling. One explanation is that the spectra may be the result of a mixture of primary and secondary ages. 
[51] The clearest relationship is a match between K-feldspar argon ages and host rock metamorphic grade whereby the diagenetic to zeolite facies Maitai Terrane gives essentially source area ages and the higher grade zeolite facies Murihiku Terrane gives post-depositional ages.

[52] We can explain the structural relationships seen at the present-day exposure level by a simple compressional model with differential vertical movement on the Hillfoot and Livingstone Faults (Figures 1 and 7). This invokes southward (back-) thrusting of the Caples Terrane over the Maitai Terrane along the Livingstone Fault and northward thrusting of the Murihiku Terrane over the Maitai Terrane along the Hillfoot Fault, perhaps concomitant with development of the steep northern limb of the Southland Syncline (Figure 1). These structures can be considered as a compressional consolidation of the arc-trench region. The Maitai Terrane, the backstop to the accretionary wedge, has remained at high structural levels throughout its post-accretionary history.

[53] Because deposition in the Murihiku forearc basin continued in the South Island until at least $160 \mathrm{Ma}$ (and to at least $130 \mathrm{Ma}$ in the North Island), no Murihiku degassing or recrystallization event matching Jurassic metamorphism in the Otago Schist would necessarily be expected. Samples GO13 and RH3 show evidence of gas release at 125-135 Ma, the same time as an increased cooling rate in the schist wedge [Little et al., 1999]. Speculatively, the thrusting and synclinal folding of Maitai and Murihiku Terranes occurred at this time. Many Maitai and Murihiku K-feldspars show evidence of resetting from 130 to $90 \mathrm{Ma}$ but ages are too imprecise to correlate (they may be mixture of primary and secondary ages). A fission track or helium geochronological study would probably extract more, and more useful, thermochronological information from the zeolite facies Mesozoic forearc rocks.

\section{Conclusions}

[54] New ${ }^{40} \mathrm{Ar}{ }^{39} \mathrm{Ar}$ K-feldspar ages from 13 low grade metasedimentary rocks across New Zealand's Eastern Province and new ${ }^{40} \mathrm{Ar} /{ }^{39} \mathrm{Ar}$ metamorphic white mica ages from three Otago Schist samples provide useful information on the thermotectonic development of an exhumed Mesozoic convergent margin. $\mathrm{K}$-feldspar grains show textural evidence for recrystallization, best revealed by $\mathrm{CL}$ images. Incremental heating spectra and laser ages yield different and complex patterns but can be interpreted as supporting thermo-tectonic links across the accretionary wedge, forearc region and magmatic arc.

[55] With careful interpretation backed by structural, metamorphic and mineralogical information, incremental step-heating and single grain laser fusion K-feldspar ages can provide useful information on the rocks in a temperature interval lower than they are normally used for. In this case study, detrital K-feldspars in diagenetic to lowermost zeolite facies host rocks (Maitai Terrane) preserve a record of source area ages. K-feldspars in zeolite facies host rocks (Murihiku Terrane) record ages 10-15 m.y. younger than depositional ages and appear to have undergone recrystallization during diagenesis as well as during post-diagenetic events; the features of the age spectra may result from a mix of gas from primary and secondary K-feldspars. K-feldspars from prehnite-pumpellyite facies rocks more obviously preserve ages related to recrystallization during low grade Jurassic regional metamorphism. Peak temperatures in all these lowgrade regional metamorphic rocks were too low for MDD modeling to be applicable, even though the Arrhenius data from some K-feldspars across all metamorphic grades ostensibly are amenable to MDD modeling. This variably retentive behavior, while not predictable, can be used to interpretive advantage as more and less retentive K-feldspars can record the timing of different thermo-tectonic events.

[56] Acknowledgments. We thank Neville Orr, John Simes, John Hunt, Andreas Auer, Luke Easterbrook, Brent Pooley and Xiaodong Zhang for essential technical support, Ross Lochhead for assistance in the field at Romahapa, and Ian Turnbull and Chris Adams for discussions. Comments on earlier versions of the manuscript by Ian Turnbull, Mark Rattenbury, Tim Little, Uwe Ring, Marion Campani and an anonymous reviewer helped to improve the final paper. The Australian Institute of Nuclear Science and Engineering and the Australian Nuclear Science Technology Organisation provided a generous grant to facilitate irradiation of the samples. This work was partially funded by the New Zealand Foundation for Research, Science and Technology and the Australian Research Council through Discovery Grant DP0208837.

\section{References}

Adams, C. J., and P. Robinson (1993), Potassium-argon age studies of metamorphism/uplift/cooling in Haast Schist coastal sections south of Dunedin, Otago, New Zealand, N. Z. J. Geol. Geophys., 36, 317-325, doi:10.1080/00288306.1993.9514578.

Adams, C. J., M. E. Barley, R. Maas, and M. G. Doyle (2002), Provenance of Permian-Triassic volcaniclastic sedimentary terranes in New Zealand: Evidence from their radiogenic isotope characteristics and detrital mineral age patterns, N. Z. J. Geol. Geophys., 45, 221-242, doi:10.1080/ 00288306.2002.9514970.

Adams, C. J., H. J. Campbell, and W. L. Griffin (2007), Provenance comparisons of Permian to Jurassic tectonostratigraphic terranes in New Zealand: Perspectives from detrital zircon age patterns, Geol. Mag., 144, 701-729, doi:10.1017/S0016756807003469.

Adams, C. J., H. J. Campbell, and W. L. Griffin (2009), Tracing the Caples Terrane through New Zealand using detrital zircon age patterns and radiogenic isotope signatures, N. Z. J. Geol. Geophys., 52, 223-245, doi:10.1080/00288300909509888.

Becker, W. N. (1973), A preliminary study of Tuapeka Group rocks in the Lower Clutha Valley, B.Sc. (Hons.) thesis, Dep. of Geol., Univ. of Otago, Otago, New Zealand.

Bishop, D. G. (1972), Progressive metamorphism from prehnite-pumpellyite to greenschist facies in the Dansey Pass area, Otago, New Zealand, Geol. Soc. Am. Bull., 83, 3177-3198, doi:10.1130/0016-7606(1972)83[3177: PMFPTG]2.0.CO;2

Bishop, D. G., and I. M. Turnbull (1996), Geology of the Dunedin area, Geol. Map, 21, scale 1:250,000, GNS Sci., Lower Hutt, N. Z.

Boles, J. R. (1991), Diagenesis during folding and uplift of the Southland Syncline, New Zealand, N. Z. J. Geol. Geophys., 34, 253-259.

Bradshaw, J. D. (1989), Cretaceous geotectonic patterns in the New Zealand region, Tectonics, 8, 803-820, doi:10.1029/TC008i004p00803.

Breeding, C. M., and J. J. Ague (2002), Slab-derived fluids and quartz-vein formation in an accretionary prism, Otago Schist, New Zealand, Geology, 30, 499-502, doi:10.1130/0091-7613(2002)030<0499:SDFAQV >2.0.CO;2

Campbell, J. D. (1987), Notes on the Triassic-Jurassic stratigraphy of South Otago, including the Kaka Point and Nugget Point coastal region, Geol. Soc. N. Z. Misc. Publ., 37B, 53-66.

Campbell, J. D., D. S. Coombs, and A. Grebneff (2003), Willsher Group and geology of the Triassic Kaka Point coastal section, south-east Otago, New Zealand, J. R. Soc. N. Z., 33, 7-38, doi:10.1080/03014223.2003. 9517719.

Campbell, J. K., and J. D. Campbell (1970), Triassic tube fossils from Tuapeka rocks, Akatore, South Otago, N. Z. J. Geol. Geophys., 13, 392-399, doi:10.1080/00288306.1970.10423975.

Cawood, P. A. (1987), Stratigraphic and structural relations of strata enclosing the Dun Mountain Ophiolite Belt in the Arthurton-Clinton region, Southland, New Zealand, N. Z. J. Geol. Geophys., 30, 19-36, doi:10.1080/00288306.1987.10422191.

Coombs, D. S. (1954), The nature and alteration of some Triassic sediments from Southland, New Zealand, Trans. R. Soc. N. Z., 82, 65-109.

Coombs, D. S., C. A. Landis, R. J. Norris, J. M. Sinton, D. J. Borns, and 
D. Craw (1976), The Dun Mountain Ophiolite Belt, New Zealand, its tectonic setting, constitution and origin, with special reference to the southern portion, Am. J. Sci., 276, 561-603, doi:10.2475/ajs.276.5.561.

Coombs, D. S., C. A. Landis, S. Hada, M. Ito, B. P. Roser, T. Suzuki, and S. Yoshikura (2000), The Chrystalls Beach-Brighton block, southeas Otago, New Zealand: Petrography, geochemistry and terrane correlation, N. Z. J. Geol. Geophys., 43, 355-372, doi:10.1080/00288306.2000.9514893.

Deckert, H., U. Ring, and N. Mortimer (2002), Tectonic significance of Cretaceous bivergent extensional shear zones in the Torlesse accretionary wedge, central Otago Schist, New Zealand, N. Z. J. Geol. Geophys., 45, 537-547, doi:10.1080/00288306.2002.9514990.

Dunlap, W. J. (1997), Neocrystallization or cooling?: ${ }^{40} \mathrm{Ar} /{ }^{39} \mathrm{Ar}$ ages of white micas from low grade mylonites, Chem. Geol., 143, 181-203, doi:10.1016/S0009-2541(97)00113-7.

Dunlap, W. J. (2003), Crystallization versus cooling ages of white micas: Dramatic effect of K-poor inclusions on ${ }^{40} \mathrm{Ar} /{ }^{39} \mathrm{Ar}$ Age spectra, J. Virtual Explor., 13, paper 3.

Dunlap, W. J., and R. Wysoczanski (2002), Thermal evidence for Early Cretaceous metamorphism in the Shyok suture zone and age of the Khardung volcanics, Ladakh, India, J. Asian Earth Sci., 20, 481-490, doi:10.1016/ S1367-9120(01)00042-6.

Dunlap, W. J., G. Hirth, and C. Teyssier (1997), Thermomechanical evolution of a ductile duplex, Tectonics, 16, 983-1000, doi:10.1029/ 97TC00614.

Fagereng, A., and A. F. Cooper (2010), The metamorphic history of rocks buried, accreted and exhumed in an accretionary prism: An example from the Otago Schist, New Zealand, J. Metamorph. Geol., 28, 935-954, doi:10.1111/j.1525-1314.2010.00900.x.

Finch, A. A., and D. L. Walker (1991), Cathodoluminescence and microporosity in alkali feldspars from the Blå Måne Sø perthosite, South Greenland, Mineral. Mag., 55, 583-589, doi:10.1180/minmag.1991.055.381.11.

Forster, M. A., and G. S. Lister (2003), Cretaceous metamorphic core complexes in the Otago Schist, New Zealand, Aust. J. Earth Sci., 50, 181-198, doi:10.1046/j.1440-0952.2003.00986.x.

Forsyth, P. J. (2001), Geology of the Waitaki area, Geol. Map, 19, scale 1:250,000, GNS Sci., Lower Hutt, New Zealand.

Frey, M., C. de Capitani, and J. G. Liou (1991), A new petrogenetic grid for low-grade metabasites, J. Metamorph. Geol., 9, 497-509, doi:10.1111/ j.1525-1314.1991.tb00542.x.

Gray, D. R., and D. A. Foster (2004), ${ }^{40} \mathrm{Ar} /{ }^{39} \mathrm{Ar}$ thermochronologic constraints on deformation, metamorphism and cooling/exhumation of a Mesozoic accretionary wedge, Otago Schist, New Zealand, Tectonophysics, 385, 181-210, doi:10.1016/j.tecto.2004.05.001.

Hampel, F. R., P. J. Rousseeuw, E. M. Ronchetti, and W. A. Stahel (1986), Robust Statistics, John Wiley, New York.

Harlavan, Y., and A. Sandler (2010), Steps towards dating early diagenetic K-feldspar by the ${ }^{40} \mathrm{Ar} /{ }^{39} \mathrm{Ar}$ method, Sediment. Geol., 229, 254-267, doi:10.1016/j.sedgeo.2010.06.012.

Harrison, T. M., M. T. Heizler, O. M. Lovera, W. Chen, and M. Grove (1994), A chlorine disinfectant for excess argon released from K-feldspar during step-heating, Earth Planet. Sci. Lett., 123, 95-104, doi:10.1016/ 0012-821X(94)90260-7.

Harrison, T. M., M. T. Heizler, K. D. McKeegan, and A. K. Schmitt (2010), In situ ${ }^{40} \mathrm{~K}-{ }^{40} \mathrm{Ca}$ 'double plus' SIMS dating resolves Klokken feldspa ${ }^{40} \mathrm{~K}-{ }^{40} \mathrm{Ar}$ paradox, Earth Planet. Sci. Lett., 299, 426-433, doi:10.1016/ j.eps1.2010.09.023.

Herman, F., J. Braun, and W. J. Dunlap (2007), Tectonomorphic scenarios in the Southern Alps of New Zealand, J. Geophys. Res., 112, B04201, doi:10.1029/2004JB003472.

Ito, M., Y. Aita, and S. Hada (2000), New radiolarian age information for the Chrystalls Beach Complex, southwest of Dunedin, New Zealand, N. Z. J. Geol. Geophys., 43, 349-354, doi:10.1080/00288306.2000.9514892.

Kimbrough, D. L., J. M. Mattinson, D. S. Coombs, C. A. Landis, and M. R. Johnston (1992), Uranium-lead ages from the Dun Mountain ophiolite belt and Brook Street terrane, South Island, New Zealand, Geol. Soc. Am. Bull., 104, 429-443, doi:10.1130/0016-7606(1992)104<0429:ULAFTD>2.3.CO;2.

Lee, J. K. W. (1995), Multipath diffusion in geochronology, Contrib. Mineral. Petrol., 120, 60-82, doi:10.1007/BF00311008.

Lee, M. R., I. Parsons, P. R. Edwards, and R. W. Martin (2007), Identification of cathodoluminescence activators in zoned alkali feldspars by hyperspectral imaging and electron-probe microanalysis, Am. Mineral., 92, 243-253, doi:10.2138/am.2007.2160.

Leichmann, J., I. Broska, and K. Zachovalova (2003), Low-grade metamorphic alteration of feldspar minerals: A CL study, Terra Nova, 15, 104-108, doi:10.1046/j.1365-3121.2003.00467.x.

Little, T. A., N. Mortimer, and M. O. McWilliams (1999), An episodic Cretaceous cooling model for the Otago-Marlborough Schist, New Zealand, based on ${ }^{40} \mathrm{Ar} /{ }^{39} \mathrm{Ar}$ white mica ages, N. Z. J. Geol. Geophys., 42, 305-325, doi:10.1080/00288306.1999.9514848.
Lovera, O. M., F. M. Richter, and T. M. Harrison (1989), The ${ }^{40} \mathrm{Ar} /{ }^{39} \mathrm{Ar}$ thermochronometry for slowly cooled samples having a distribution of diffusion domain sizes, J. Geophys. Res., 94, 17,917-17,935, doi:10.1029/JB094iB12p17917.

Lovera, O. M., M. Grove, and T. M. Harrison (2002), Systematic analysis of K-feldspar ${ }^{40} \mathrm{Ar} /{ }^{39} \mathrm{Ar}$ step-heating results: II. Relevance of laboratory argon diffusion properties to nature, Geochim. Cosmochim. Acta, 66, 1237-1255, doi:10.1016/S0016-7037(01)00846-8.

MacKinnon, T. C. (1983), Origin of the Torlesse terrane and coeval rocks, South Island, New Zealand, Geol. Soc. Am. Bull., 94, 967-985, doi:10.1130/ 0016-7606(1983)94<967:OOTTTA>2.0.CO;2.

McDougall, I., and T. M. Harrison (1999), Geochronology and Thermochronology by the ${ }^{40} \mathrm{Ar}{ }^{\beta 9} \mathrm{Ar}$ Method, 2nd ed., Oxford Univ. Press, New York. McDougall, I., and Z. Roksandic (1974), Total fusion ${ }^{40} \mathrm{Ar} /{ }^{39} \mathrm{Ar}$ ages using HIFAR reactor, J. Geol. Soc. Aust., 21, 81-89, doi:10.1080/ 00167617408728836

McLaren, S., and W. J. Dunlap (2006), Use of ${ }^{40} \mathrm{Ar} /{ }^{39} \mathrm{Ar} \mathrm{K}$-feldspar thermochronology in basin thermal history reconstruction: An example from the Big Lake Suite granites, Warburton Basin, South Australia, Basin Res., 18, 189-203, doi:10.1111/j.1365-2117.2006.00288.x.

McLaren, S., W. J. Dunlap, and R. Powell (2007), Understanding K-feldspar ${ }^{40} \mathrm{Ar} /{ }^{39} \mathrm{Ar}$ data: Reconciling models, methods and microtextures, J. Geol. Soc., 164, 941-944, doi:10.1144/0016-76492006-180.

Mortimer, N. (1993), Jurassic tectonic history of the Otago Schist, New Zealand, Tectonics, 12, 237-244, doi:10.1029/92TC01563.

Mortimer, N. (2000), Metamorphic discontinuities in orogenic belts: Example of the garnet-biotite-albite zone in the Otago Schist, New Zealand, Int. J. Earth Sci., 89, 295-306, doi:10.1007/s005310000086.

Mortimer, N. (2003), A provisional structural thickness map of the Otago Schist, New Zealand, Am. J. Sci., 303, 603-621, doi:10.2475/ajs.303.7.603.

Mortimer, N. (2004), New Zealand's geological foundations, Gondwana Res., 7, 261-272, doi:10.1016/S1342-937X(05)70324-5.

Mortimer, N., A. J. Tulloch, R. N. Spark, N. W. Walker, E. Ladley, A. H. Allibone, and D. L. Kimbrough (1999), Overview of the Median Batholith, New Zealand: A new interpretation of the geology of the Median Tectonic Zone, J. Afr. Earth Sci., 29, 257-268, doi:10.1016/S08995362(99)00095-0.

Mortimer, N., F. J. Davey, A. Melhuish, J. Yu, and N. J. Godfrey (2002), Geological interpretation of a deep seismic reflection profile across the Eastern Province and Median Batholith, New Zealand: Crustal architecture of an extended Phanerozoic convergent margin, N. Z. J. Geol. Geophys., 45, 349-363, doi:10.1080/00288306.2002.9514978.

Nishimura, Y., D. S. Coombs, C. A. Landis, and T. Itaya (2000), Continuous metamorphic gradient documented by graphitization and $\mathrm{K}-\mathrm{Ar}$ age, southeast Otago, New Zealand, Am Mineral., 85, 1625-1636.

Parsons, I., W. L. Brown, and J. V. Smith (1999), ${ }^{40} \mathrm{Ar} /{ }^{39} \mathrm{Ar}$ thermochronology using alkali feldspars: Real thermal history or mathematical mirage of microtexture?, Contrib. Mineral. Petrol., 136, 92-110, doi:10.1007/ s004100050526.

Powell, R., J. Woodhead, and J. Hergt (2002), Improving isochron calculations with robust statistics and the bootstrap, Chem. Geol., 185, 191-204 doi:10.1016/S0009-2541(01)00403-X.

Rahl, J. M., M. T. Brandon, H. Deckert, U. Ring, and N. Mortimer (2011), Tectonic significance of ductile deformation in low-grade sandstones in the Mesozoic Otago subduction wedge, New Zealand, Am. J. Sci., 311, 27-62, doi:10.2475/01.2011.02.

Renne, P. R., C. C. Swisher, A. L. Deino, D. B. Karner, T. L. Owens, and D. J. DePaolo (1998), Intercalibration of standards, absolute ages and uncertainties in ${ }^{40} \mathrm{Ar} /{ }^{39} \mathrm{Ar}$ dating, Chem. Geol., 145, 117-152, doi:10.1016/S0009-2541(97)00159-9.

Richter, F. M., O. M. Lovera, T. M. Harrison, and P. Copeland (1991), Tibetan tectonics from ${ }^{40} \mathrm{Ar} /{ }^{39} \mathrm{Ar}$ analysis of a single K-feldspar sample, Earth Planet. Sci. Lett., 105, 266-278, doi:10.1016/0012-821X(91) 90136-6.

Sherlock, S. C., T. Lucks, S. P. Kelley, and A. Barnicoat (2005), High spatial resolution ${ }^{40} \mathrm{Ar} /{ }^{39} \mathrm{Ar}$ laser probe analysis of complex polygenetic K-feldspar overgrowths: A record of sandstone burial and tectonically driven fluid migration, Earth Planet. Sci. Lett., 238, 329-341, doi:10.1016/j.epsl.2005.07.018.

Stallard, A., and D. Shelley (2004), Structural architecture of the Otago Schist: Accretionary prism, collisional orogen or core complex?, Geol. Soc. N. Z. Misc. Publ., 117A, 100.

Steiger, R., and E. Jaeger (1977), Subcommission on geochronology: Convention on the use of decay constants in geo- and cosmochronology, Earth Planet. Sci. Lett., 36, 359-362, doi:10.1016/0012-821X(77)90060-7.

Tetley, N., I. McDougall, and H. R. Heydegger (1980), Thermal neutron interferences in the ${ }^{40} \mathrm{Ar} /{ }^{39} \mathrm{Ar}$ dating technique, J. Geophys. Res., 85, 7201-7205, doi:10.1029/JB085iB12p07201. 
Tippett, J. M., and P. J. J. Kamp (1993), Fission track analysis of the late Cenozoic vertical kinematics of continental Pacific crust, South Island, New Zealand, J. Geophys. Res., 98, 16,119-16,148, doi:10.1029/92JB02115.

Tulloch, A. J., and D. L. Kimbrough (2003), Paired plutonic belts in convergent margins and the development of high $\mathrm{Sr} / \mathrm{Y}$ magmatism: Peninsular Ranges batholith of Baja-California and Median batholith of New Zealand, Spec. Pap. Geol. Soc. Am., 374, 275-295.

Turnbull, I. M. (1979), Stratigraphy and sedimentology of the Caples terrane of the Thomson Mountains, northern Southland, New Zealand, N. Z. J. Geol. Geophys., 22, 555-574, doi:10.1080/00288306.1979. 10424166 .
Turnbull, I. M. (2000), Geology of the Wakatipu area, Geol. Map, 18, scale 1:250,000, GNS Sci., Lower Hutt, New Zealand.

Turnbull, I. M., and A. H. Allibone (2003), Geology of the Murihiku area, Geol. Map, 20, scale 1:250,000, GNS Sci., Lower Hutt, New Zealand.

Waddell, S. J. (1969), The geology of the Romahapa area, south-east Otago, Dip. Sci. thesis, Dep. of Geol., Univ. of Otago, Otago, New Zealand.

Warnock, A. C., and P. C. van der Kamp (1999), Hump-shaped ${ }^{40} \mathrm{Ar} /{ }^{39} \mathrm{Ar}$ age spectra in K-feldspar and evidence for Cretaceous authigenesis in the Fountain Formation near Eldorado Springs, Colorado, Earth Planet. Sci. Lett., 174, 99-111, doi:10.1016/S0012-821X(99)00250-2.

Wood, B. L. (1956), The geology of Gore subdivision, N. Z. Geol. Surv. Bull., 53, $127 \mathrm{pp}$. 


\section{University Library}

\section{- M M I N E R VA \\ A gateway to Melbourne's research publications}

Minerva Access is the Institutional Repository of The University of Melbourne

Author/s:

Mortimer, N;McLaren, S;Dunlap, WJ

Title:

Ar-Ar dating of K-feldspar in low grade metamorphic rocks: Example of an exhumed Mesozoic accretionary wedge and forearc, South Island, New Zealand

Date:

2012-06-30

Citation:

Mortimer, N., McLaren, S. \& Dunlap, W. J. (2012). Ar-Ar dating of K-feldspar in low grade metamorphic rocks: Example of an exhumed Mesozoic accretionary wedge and forearc, South Island, New Zealand. TECTONICS, 31 (3), https://doi.org/10.1029/2011TC003057.

Persistent Link:

http://hdl.handle.net/11343/112397 